\title{
SUBSIDIARUMO APRAIŠKOS IR PERSPEKTYVOS ŠEIMOS POLITIKOJE LIETUVOJE
}

\author{
Lijana Gvaldaitè, Agnija Kirilova \\ Vilniaus universitetas
}

\begin{abstract}
Anotacija
Straipsnyje aptariamos šeimos politikos tendencijos Lietuvoje subsidiarumo koncepcijos kontekste. Šeimos politika mūsų šalyje nẻra subsidiari, tačiau pastaraji dešimtmeti galima ižvelgti tam tikrų subsidiarumo principo taikymo Lietuvoje pavyzdžių: per nevyriausybinio sektoriaus veiklą, bendruomenių ir šeimų dalyvavimą kuriant šeimos politiką. Pasitelkus literatūros, teisės aktų, dokumentų analizę ir ekspertų interviu ižvalgas vertinamos šio principo įtvirtinimo ir plètotès mūsų šalyje galimybès. Straipsnyje atkleidžiama, kad subsidiarumas leidžia suaktyvinti pilietini sektorių, kurti ir igyvendinti $\mathfrak{i}$ žmogų bei jo igalinimą nukreiptas strategijas, mažinti valstybinių institucijų kontrolę ir išlaidas.

PAGRINDINIAI ŽODŽIAI: subsidiarumas, šeimos politika, šeimų savigalba ir bendruomeniškumas, igalinimas.
\end{abstract}

\begin{abstract}
This article analyzes the family policy in Lithuania in the light of the concept of subsidiarity. Family policy in Lithuania is not subsidiary but the last decade have seen some examples of the application of subsidiarity through the activities of the non-governmental sector as well as communities' and families' participation in development of the family policy. According to the analysis of literature, law, documents and experts' interviews insights, the article delineates the assumptions of the development and entrenchment of the principle of subsidiarity in Lithuania. The analysis shows how the principle of subsidarity provides opportunities to revitalize the civil sector develop and implement human-centered and empowerment strategies and reduce the public authorities control mechanisms and operation costs.
\end{abstract}

KEY WORDS: subsidiarity, family policy, self-help and communities of families, empowerment.

\section{Ivadas}

Kai kurių tyrejų ir socialinės politikos ekspertų teigimu, subsidiarumo tema vis labiau aktualèja mažèjant valstybiu, kartu ir gerovès valstybių, galimybėms pasirūpinti visomis gyventojų socialinėmis rizikomis (Szczepaniak, 2010; Donati, 2007, 2011; Brugnoli Vittadini, 2008 ir kt.). Ši sritis aprèpia platų veiksnių lauką - finansinius išteklius, jų perskirstyma, paslaugu ir pagalbos organizavima, kt., taip pat ir pilietinès visuomenès bei mažesnių socialinių grupių - nevyriausybinių organizacijų (NVO), vietos bendruomenių, savivaldybių, šeimų ir pavienių asmenų - dalyvavimo klausimą formuojant socialinès ir šeimos politikos kryptis bei jas igyvendinant. Remiantis subsidiarumo principu teigiama, kad tokios politikos aktyvūs veikèjai gali būti ne tik valstybinès institucijos, bet ir įvairios savarankiškos, ,iš apačios““ kilusios iniciatyvos: jų dalyvavimas užtikrina išsamesnị ir tikslesnị piliečių porei- 
kių pažinimą ir gali paskatinti prisidèti formuojant veiksmingesnę politika, taip kurti daugiadimensi welfare modeli.. Subsidiarumas gali sudaryti sąlygas taikyti ivairias piliečių dalyvavimo ir atstovavimo formas, skatinti $\mathfrak{i}$ asmeni orientuotas pagalbos strategijas ir igalinimą. Taikant ši principą galima siekti veiksmingesnès pagalbos asmenims, mažinti valstybinių institucijų kontrolę ir išlaidas. Kartu akivaizdu, kad tokios sistemos valdymo logika yra specifine, jis gana sudètingas ir, be privalumų, turi nemažai dilemų bei rizikų. Be to, tam būtinos tam tikros socialinėspolitinès sąlygos, „solidaristinis“ mentalitetas.

Mūsų šalyje šeimos politika nėra subsidiari, tačiau galima ižvelgti tam tikrų subsidiarumo apraiškų: per šeimu ir jų asocijuotų darinių ịsitraukimą, NVO, teikiančiu paslaugas šeimoms ir veikiančiu šeimų gerovés labui, veiklą, savivaldybių ir bendruomeniu iniciatyvas. Šeimos politikos nagrinejjimas šiuo aspektu reikšmingas tiek moksliniu, tiek praktiniu požiūriais, nes tyrimų ir platesnių diskusijų, $\mathfrak{i}$ kurias įsitrauktų mokslininkai bei su šia sritimi susiję specialistai ar pačios šeimos, stokojama.

Nors subsidiarumas dar mažai tirtas ne tik Lietuvoje, bet ir tarptautiniu lygiu, mūsų šalyje ši koncepcija pastaraisiais metais vis dažniau patraukia ekonomikos, vadybos, socialinės politikos ir socialinio darbo, kitų sričių atstovų dèmesị: apie tai rašè V. Kondratienè (2011), E. Laumenskaitè (2011), L. Gvaldaitè (2004, 2006, 2012), Ž. Markauskaitė (2005), D. Petružyte, S. Girdzijauskienè (2004) ir kiti. Tačiau apskritai pasakytina, kad trūksta informacijos ir išsamesnių tyrimų šia tematika.

Šiame straipsnyje nagrinejami subsidiarumo principo teoriniai pagrindai ir jo apraiškos bei perspektyvos dabartinejje Lietuvos šeimos politikoje. Pasirinktai tematikai atskleisti taikyti šie tyrimo metodai: lyginamoji mokslinès literatūros, teisès aktų, dokumentų analizè, iš dalies struktūruotas ekspertų interviu.

\section{Subsidiarumo principo teorinès prielaidos ir igyvendinimo galimybès}

Subsidiarumo samprata iprastai siejama su decentralizavimu, federalizmu, solidarumu, asmenų ir organizacijų igalinimu, kt. Šie veiksniai yra sudedamosios subsidiarumo dalys, tačiau ne visiškai atsako, koks sudètingas tai yra fenomenas ir koks kompleksiškas šio principo igyvendinimas (Donati, 2011). Subsidiarumo principą (lot. subsidium - pagalba) glaustai galima apibūdinti kaip aukštesniųjų struktūrų ar institucijų (valstybès, regiono ir miesto) pagalbą žemesniesiems (asmeniui, šeimai, bendruomenei, nevyriausybinio sektoriaus organizacijoms). Subsidiarumas, galima sakyti, apima dvi pagrindines idejas: visų pirma pavienių asmenų ir mažesnių organizacijų dalyvavimą, atsižvelgiant $i$ jų galimybes ir gebé- 
jimus, kuriant savą ir bendrą gerovę, stipresnèms institucijoms apsiribojant veikla tose srityse, kur mažesnès institucijos nèra pajègios; antra, didesnès institucijos, ypač valstybè, padeda žemesniosioms grandims taip, kad pastarosios galètų veikti ir daryti tai, ką sugeba (Compendio della dottrina sociale della Chiesa, 2005).

Subsidiarumo apibrèžčiu kompleksiškumui susidaryti neabejotinai itakos turèjo subsidiarumo filosofinès antropologinès ir politinès ištakos. Nagrinejjant mokslinę literatūra, galima aptikti skirtingą subsidiarumo principo ištakų traktavimą: manoma, kad jos siekia net antikos laikus, kai subsidiarumo idèja buvo išreiškiama per asmens, visuomenès ir valstybès santykị, pabréžiant poreiki burtis, siekiant patenkinti socialinius interesus (Kondratienè, 2011). Bet kuriuo atveju sutariama, kad pirminè subsidiarumo principo samprata, kuri vartojama iki šiol, suformuluota krikščioniškojo socialinio mokymo atstovų XX amžiuje (Petružyte, Girdzijauskienė, Gvaldaitė, 2004; Kondratienè, 2011). Popiežius Pijus XI enciklikoje „Quadragesimo Anno“ 1931 m. (Pio XI, 1999) pats pirmas suformulavo subsidiarumo principa (užuomazgos aptinkamos ir anksčiau - popiežiaus Leono XIII $1891 \mathrm{~m}$. enciklikoje „Rerum novarum“), toliau šią koncepciją plètojo ir kiti popiežiai (ypač Jonas Paulius II), o pastaraisiais metais Bažnyčios socialinį mokymą ryškiai papildo popiežių Bendikto XVI ir Pranciškaus darbai. V. Kondratienès teigimu (2011), jau pirmojoje enciklikoje ittvirtinamas modelis, kuriuo remiantis, asmuo veikia savarankiškai, ,iš viršaus“ jam „,nenuleidžiant“" pagalbos ir sprendimų - poreikiai ir socialinè struktūra formuojami ,iš apačios“. Prisiimdamas atsakomybę už save, naudodamasis tais ištekliais, kurie jam priimtiniausi, jis pasirenka tai, kas jam geriausia, ir pats yra pajègus užsitikrinti savo gerovę. Principo idèja nèra ir visiškai perduoti atsakomybę asmeniui ir juo nesirūpinti, bet subsidijuoti tais atvejais, kai šis savarankiškai negali pasirūpinti savo gerove. Be to, svarbu, kad asmuo turètu galimybę rinktis. Taigi valstybė nelieka tik pasyvi stebètoja - ji turi sudaryti sąlygas veikti asmeniui ir jo artimiausiai aplinkai. Šiuos akcentus lemia subsidiarumo principo esmè - požiūris į žmogų kaip laisvą, nelygstamą, orų asmenį, kuris yra visų socialinių institucijų šaltinis, objektas ir tikslas. Jei asmuo apibréžiamas kaip nuolat ir natūraliai atviras kitiems, susijęs su kitais, t. y. santykiškas, ir taip realizuojantis savo prigimtini socialumą, dèmesys kreipiamas i jo pirminius - šeiminius ryšius, priklausymo bendruomenes, taip pat ir į tarpines grandis tarp šeimos ir valstybès - nevyriausybines organizacijas.

Subsidiarumo ideja krikščioniškajame socialiniame mokyme atskleidžiama ir kaip valstybès bei savanorišku pagrindu susivienijusių organizacijų (nevyriausybinių organizaciju, bendruomenès ir pan.) veiklos reguliavimo principas. Tame lygmenyje, kuriame susivienijusios organizacijos gali veikti savarankiškai, valstybė negali apriboti jų veiklos ir pati atlikti numatytų funkcijų: valstybẻ ir savanoriškai 
susivienijusios organizacijos, laikantis subsidiarumo principo, glaudžiai ir aktyviai tarpusavyje bendradarbiauja, teikdamos paslaugas yra partnerès.

Subsidiarumo principas gali būti taikomas ịvairiose srityse ir skirtinguose lygmenyse - mikro-, mezzo- ir makro-. Šiuolaikinejje mokslo doktrinoje subsidiarumas suprantamas kaip principas, kuris ittvirtintas Europos Bendrijos teiseje, todèl siejamas su politine sistema ir funkciju pasiskirstymu Europos Sajungoje (Kondratienè, 2011). Maastricht'o sutarties 3b straipsnyje teigiama, kad „srityse, kurios nepatenka į Bendrijos išimtinę kompetenciją, Bendrija, vadovaudamasi subsidiarumo principu, veikia tik tada, kai pasiūlytas veiksmas negali būti tinkamai ìvykdytas valstybių narių ir dèl pasiūlyto veiksmo masto ar poveikio Bendrija ji atliktu geriau. Vadinasi, reglamentavimas Bendrijos lygiu yra prasmingas tada, kai konkreti problema peržengia nacionalines sienas ir negali būti tinkamai išspręsta vienos ar kelių valstybių narių nacionalinèmis priemonėmis, tačiau gali būti išspręsta Bendrijos priemonėmis“" (Maastricht sutartis, 1993 vertimas $^{1}$ ). Minètoje sutartyje itvirtinamas principas, kuriuo remdamosi Europos Sajungos šalys nepraranda savo identiteto ir išlaiko demokratini stabilumą bei ittvirtina nuostatą priimti sprendimus, kurie būtų naudingesni piliečiams. Kadangi Europos Sajungos valstybių narių politinès sistemos ir pasaulèžiūros yra skirtingos, jos puoselëja savas tradicijas, subsidiarumo principas padeda išsaugoti valstybių savitumą, suderinti skirtingus valstybių interesus ir pasiekti, kad būtų priimti veiksmingiausi kompromisiniai sprendimai, užtikrinantys kiekvienos šalies piliečių gerovę ir Europos Sajungos, kaip vieningos bendrijos, gerovę (Kondratienè, 2011).

1997 metais priimta Amsterdamo sutartis išaiškina subsidiarumo principo taikymą Europos Sajungos ir nacionalinès valdymo politikos kontekste. Taikant ši principa, tinkamai reguliuojamas kompetencijų pasiskirstymas ir sprendimų prièmimas tarp Bendrijos ir valstybiu bei valstybių viduje. Remdamasi šiuo principu, Bendrija gali veikti pagal savo kompetencija, jeigu aplinkybès to reikalauja, tačiau neturi viršyti savo igaliojimų tose srityse, kur to nereikalaujama. Subsidiarumo principas aktualizuojamas ne tik Europos Sajungos, kaip darinio, lygmenyje, bet ir kiekvienoje šalyje. Be abejonès, tai priklauso nuo šalies konstitucinès teisès nuostatų, sociali-

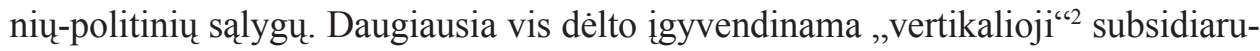

1 Nacionalinès teisès aktų derinimo su Europos Sajungos teise metodiniai nurodymai patvirtinti Europos teisès departamento prie Lietuvos Respublikos Vyriausybès generalinio direktoriaus 1999 m. gruodžio 24 d. įsakymu Nr. 19.

2 Socialinejje politikoje ir kitose srityse išskirtinos dvi subsidiarumo rūšys: vertikalusis ir horizontalusis. Vertikalioji subsidiarumo dimensija apibūdina tinkamą kompetencijų paskirstymą viešajame sektoriuje, santykius tarp įvairaus lygio valstybinių instituciju (valstybès, regionų, savivaldybès). Praktinis vertikalaus subsidiarumo pavyzdys yra administracinis decentralizavimas. O horizontalusis susijęs su santykių tarp valstybès ir pilietinès visuomenès reguliavimu, kompetencijų paskirstymu tarp valstybès ir 
mo dimensija, siejama su administraciniu decentralizavimu, kompetenciju paskirstymu, stipresniujų pagalba silpnesniesiems. Tik kai kuriose šalyse (pavyzdžiui, Vokietijoje, Italijos Lombardijos regione), laikantis šio principo, stengiamasi stiprinti pilietinę visuomenę ir ją įtraukti į bendrojo gério kūrimo procesą (Gvaldaitè, 2012).

Bene aiškiausiai subsidiarumo principo igyvendinimas matomas per NVO veiklą ir bendradarbiavimą su valstybiniu, verslo bei privačiu sektoriais. Nors visuotinai pripažistama, kad NVO gali teikti kokybiškas socialines bei kitas paslaugas ir taip veiksmingiau reaguoti $\mathfrak{i}$ kilusias problemas, NVO dalyvavimas formuojant ir igyvendinant socialinę bei šeimos politiką Lietuvoje vertinamas skirtingai. Nepaprasta užtikrinti nuolatini, glaudų bendradarbiavimą tarp skirtingų sektorių, kai valdžios institucijų požiūris į NVO nėra vienareikšmiškai teigiamas, o bendradarbiavimo santykiai nesistemingi ir dèl to, kad trūksta įstatymiškai reglamentuotų bendradarbiavimo sutarčių. NVO veikla ne visada pastebima, kadangi veikia vietos iniciatyvos lygmenyje ir dẻl žmogiškuju bei finansinių išteklių stokos negali plèsti ir stiprinti savo pozicijų. R. Jančaitytès teigimu, „šiandien Lietuvoje sprendimų prièmime dažniausiai dalyvauja valstybinès institucijos ne vien todèl, kad NVO dar nėra pakankamai stiprios, bet ir todèl, kad daugelis jų yra priklausomos nuo vyriausybès finansavimo ir dèl baimès jos netekti bijo kritikuoti valdžios veiksmus“" (Jančaitytès, 2011, p. 138). O pilietinio sektoriaus atstovai tikisi finansinès ir politinès paramos iš valstybinio sektoriaus, kuris to nenori ir nesugeba suteikti.

Kkita vertus, kaip nurodoma atliktame Nevyriausybinių organizacijų informacijos ir paramos centro tyrime dèl Lietuvos NVO bendradarbiavimo su valstybės ir savivaldybių institucijomis bei įstaigomis, patys NVO nariai ne visada supranta savo vaidmeni formuojant politinius procesus ir juose dalyvaujant, nežino, kaip adresuoti prašymus ir pasiūlymus. Valstybès tarnautojai savo ruožtu teigia, kad NVO dèl administracinių gebejjimų trūkumo neretai nepajègia bendradarbiauti kaip lygiaverčiai partneriai darbo grupėse. Be to, paplitęs požiūris, kad valstybės tarnautojai nepakankamai gerai žino apie nevyriausybines organizacijas, specifinius jų veiklos aspektus ir sąlygas, bendradarbiavimui pasirenka tik tas organizacijas, kurios yra finansiškai priklausomos arba kurių reiškiama nuomone „,patogi“, atitinka valdymo institucijų tikslus ir ketinimus. Pastebèta, kad skirtingos valdymo institucijos taiko nevienodus bendradarbiavimo standartus ir praktiką, skiriasi požiūris į bendradarbiavimą su NVO (NISC, 2006, p. 24-25). Lietuvoje egzistuoja valdžios institucijų konsultacijų praktika su NVO, tačiau neaišku, kaip atrenkamos organizacijos, atstovaujančios ir ginančios piliečių interesus, nes teisiškai nereglamentuoti kriterijai, kuriuos taikant organizacijos galètų būti atrinktos.

nevyriausybiniu organizacijų. Svarbu tai, kad abiem subsidiarumo atvejais valstybe nèra pasyvi stebėtoja ar prižiūrètoja, ji turi sudaryti sąlygas, remti ir skatinti savivaldos institucijų bei trečiojo sektoriaus veiklą (Donati, 2007). 
Kalbant apie NVO, veikiančias šeimos gerovės srityje, Socialinės apsaugos ir darbo ministerijos duomenimis (www. socmin.lt) organizacijos dažniausiai skirstomos i dvi grupes:

- šeimas vienijančios organizacijos: jos gali būti formalios ir neformalios, dažniausiai sprendžia ne tik šeimos ir tèvų interesų gynimo, bet ir jų atstovavimo klausimus;

- paslaugas šeimai teikiančios organizacijos, kurios siekia tenkinti įvairius šeimų poreikius ir suteikti pagalbą šeimos nariams, kilus ịvairaus pobūdžio problemoms; šios organizacijos atstovauja šeimų interesams.

Nuo 2009 m. organizacijos gali dalyvauti „Nevyriausybinių organizacijų, dirbančiu šeimos gerovès srityje, veiklos projektų konkursuose" ir gauti finansinę paramą (nors ir negausią) plètoti veiklą, kuri nukreipta į šeimos instituto stiprinima.

Pravartu pakartoti, kad kuriant šeimos politiką ir teikiant šeimoms paslaugas svarbus vaidmuo tenka ne tik organizacijoms, bet ir įvairiems neformaliems dariniams, kurie neturi juridinio statuso - bendruomenems, klubams, taryboms, grupėms, forumams ir kt., pagaliau pačioms šeimoms. Pastaraisiais metais, kaip matysime kitame paragrafe, galima pastebèti daugiau tokių pilietinio dalyvavimo pavyzdžių.

\section{2. Šeimos politikos tendencijos Lietuvoje ir subsidiarumas}

Dèl straipsnio apimties apribojimų mūsų šalies šeimos politikos neanalizuosime, tik paminèsime kai kuriuos straipsnio temai aktulius aspektus. Tyrëjų ir ekspertu požiūriu, šeimos politika Lietuvoje išvystyta menkai, jos raidai būdingas nenuoseklumas, fragmentiškumas. Galima konstatuoti, kad iki šiol šeimos politika apsiriboja materialine pagalba stokojančioms šeimoms ir padarinių šalinimu, issikišimu skubos atvejais, be to, šiai sričiai būdingas stiprus sektorizavimas: išsiskirstymas i pavienių šeimos narių poreikių tenkinimą ir problemų sprendimą.

Šiandien vis dar sudètinga apibrèžti mūsų šalies šeimos politiką, jos vietą: svarstoma, ji traktuotina kaip savarankiška sritis ar yra sudètine socialinès politikos dalis ir igyvendinama per kitas politikos sritis - demografinę, vaiko gerovès, užimtumo, skurdo ir atskirties, lyčių lygybès, kt. A. Maslauskaitė (2005) šeimos politiką apibūdina kaip viešosios politikos dali, kuri gali būti apibrěžta kaip valstybès iniciuojamų ir/arba igyvendinamų socialinių, ekonominių priemonių kompleksas, nukreiptas į šeimos - jos struktūros ir gyvenimo kokybès - modeliavimą. Tačiau iki šiol nèra vieningos nuomonès, kurias viešosios politikos sritis galima priskirti šeimos politikai ir ką konkrečiai gali modeliuoti valstybè. 
Nagrinejjant socialinès paramos ịstatymus, pasigendama požiūrio į šeimą, kaip i savarankišką ir integralu darini, o ne paskiru asmenu grupę, kuriai reikia palankiu gyvenimo sąlygų. Socialinè parama teikiama pajamų testavimo principu ir nukreipta i̇ savarankiškumo ugdymą bei orių pragyvenimo sąlygų užtikrinimą, teikiama individualizuotai, tai yra pavieniams šeimoms nariams, siekiant apsaugoti motinystę, tèvystę, vaikystę. O prie lengvatų šeimoms galima būtų priskirti nebent būsto kredito lengvatas, o tai ypač aktualu jaunoms ir daugiavaikèms šeimoms.

LR Darbo kodekse ittvirtintos nuostatos dèl lanksčių darbo sąlygų ir formu igyvendinimo iš dalies prisideda prie šeimai palankios aplinkos kūrimo ir sudaro sąlygas šeimoms prižiūrèti bei rūpintis savarankiškai vaikais ir sergančiais asmenimis. LR Darbo kodekse ittvirtinta galimybe dirbti nuotoliniu būdu, be to, ittvirtintos lankstaus darbo grafiko ir vienos papildomos laisvos dienos, kuri skiriama asmenims, auginantiems vaikus, pasirinkimo garantijos. Tačiau ju igyvendinimas, kaip teigia tyrejjai ir ekspertai, kol kas labai vangus ir, nesant mokesčiu lengvatų sistemos, priklauso nuo privačios darbdavių iniciatyvos.

E. Laumenskaitès (2011) teigimu, reikètu išskirti šeimos politiką ir politiką, skirtą šeimai. Autorès nuomone, nors tai yra dvi skirtingos sąvokos, jos yra glaudžiai susijusios. „Lietuvoje daugiau igyvendinama politika šeimai (family policy), kuri pasižymi tik finansine parama ir funkciniu požiūriu į šeimą. Igyvendinant tokią siaurą politiką, šeima nureikšminama kaip pirminè bendruomenè ir nėra skatinamas socialinio kapitalo kūrimas, nèra kuriama palanki aplinka šeimoms, o i ši institutą žiūrima kaip į individų darinị, kuris remiamas piniginemmis išmokomis gimstamumui didinti““ (Laumenskaitè, 2011, p. 30-31).

Mokslinëje literatūroje taip pat galima aptikti šeimos politikos skirstymo į tiesioginę šeimos politiką (angl. explicit) ir netiesioginę šeimos politiką (angl. implicit) atvejų. Tiesioginès šeimos politikos gavejai yra šeimos, kurioms skiriamos priemonès ir paslaugos. Prie tiesioginès politikos priemonių galima priskirti išmokas šeimoms (vaiko išmokos, motinystès / tèvystės pašalpos ir kt.), teikiamas socialinio darbo paslaugas, psichologines konsultacijas, šeimos terapiją ir kitas paslaugas, vaikų priežiūros infrastruktūros plètrą ir pan. Tuo tarpu netiesioginè šeimos politika nukreipta i šeimos gyvenimo sąlygų gerinimą ir palankios aplinkos kūrimą. Prie netiesioginès šeimos politikos galima būtų priskirti tas priemones, kuriu poveikis šeimoms yra netiesioginis, kaip antai darbo rinkos politikos priemonès, užtikrinančios geresni šeimos ir darbo issipareigojimų derinimą (pvz., lanksčiu darbo formų deigimas), palanki šeimoms būsto politika, mokesčių lengvatos, švietimo sistemos priemonès. Dažnai, kaip rodo ir užsienio šaliu patirtis, būtent netiesioginès priemonès gerina šeimų ekonominę padètí, skatina prokreacinę funkciją ir pan. Subsidiarumas šeimos politikoje geriausiai galètu pasireikšti būtent per netiesioginę šeimos politiką. Valstybès vaidmuo tokiu atveju būtų užtikrinti palankias 
sąlygas šeimai nepažeidžiant jų autonomijos, bet jas palaikant ir teikiant joms paramą (Stankūnienè, 2001, 2005; Jančaitytė, 2006, 2011; Szczepaniak, 2010).

Koks šeimos politikos ar paramos šeimos politikai modelis bus igyvendinamas valstybėje lemia valstybès istorinè, kultūrinè, socialinė ir ekonominè sankloda, politiniu jègu ypatumai, vyraujantis socialinès politikos modelis (Maslauskaité, 2005). Tyrejjai (Stankūnienè ir kt. 2001; Jasilionienė 2005; Jančaitytė 2011) akcentuoja, kad Lietuvoje šeimos politika formuojama kaip reakcija i esamojo laiko šeimu gyvenimo problemas, tačiau nebandyta suvokti ilgalaikių sprendimu poveikio šeimos politikai. R. Jančaitytės teigimu (2011), pagrindinès šeimos politikos problemos yra nenuoseklumas, vyraujančios tradicijos ir nepalankus darbdavių požiūris. Anot V. Stankūnienès ir kt. (2005), šeimos politika yra sudedamoji socialinès gerovès politikos dalis, todèl šeimos politiką galima nagrinèti remiantis gerovès valstybių modeliais ${ }^{3}$. Mokslininkų (Stankūnienè ir kt. 2001; Maslauskaitė 2005) teigimu, Lietuva nuejo panašiu keliu, kaip ir kitos Baltijos regiono šalys: dèl panašios istorinès praeities, biudžeto ribotumų ir tarptautinių organizacijų rekomendacijų, Lietuva ir kitos regiono šalys taiko konservatyviam modeliui būdingą aprūpinimo tvarką. Tačiau galima aptikti ir socialdemokratiniam modeliui būdingu savybių: universalios šeimos pašalpos, kurios nepriklauso nuo dalyvavimo darbo rinkoje ir gaunamų pajamu. Galima teigti, kad Baltijos šalyse vyrauja „hibridinis“ gerovès valstybės tipas. Vieni autoriai teigia, kad šiame modelyje sujungtas konservatyvusis ir socialdemokratinis tipai (Maslauskaite cit. Rostrgraad, 2005), kitu požiūriu (Guogis, 2002), Lietuva gali būti traktuojama kaip tarpinè tarp konservatyviosios ir liberaliosios socialinès gerovès sistemu. A. Maslauskaitès teigimu (2005), Lietuvą galima būti apibūdinti kaip neokonservatyvią gerovès valstybę, kuri turètų būti orientuota ị tokị tarpininkavimo tarp rinkos ir šeimos modelị, kuris užtikrintų konkurencingą ekonomiką, kartu - šeimos gerovei palankią aplinką.

Vienas pirmujų dokumentu, apibrèžiančių šeimos politiką, jos kryptis ir esmę, buvo 1995 metais mokslininkų ir politiku parengta ir 1996 metais Vyriausybès patvirtinta Šeimos politikos koncepcija. Joje šeimos politika ịvardyta kaip vyriausybinių ir nevyriausybinių institucijų veiksmai, kuriu tikslas - išreikšti šeimos modelio prerogatyvas, kurti sąlygas šeimų autonominiam funkcionavimui, remti šeimas, joms realizuojant savo funkcijas, skatinti šeimas ir jų narius atlikti savo funkcijas, privalomas šeimai ir visuomenei (Dèl šeimos politikos koncepcijos ir veiksmų krypčių, 1996).

3 Vyrauja tendencija vadovautis mokslininko G. Esping-Andersen išskirtais gerovès valstybių tipologijomis, skiriant geroves valstybes i liberaluji (JAV, JK, Airija), konservatyvuji (Austrija, Prancūzija, Vokietija, Olandija), socialdemokratini (Švedija, Danija, Norvegija) bei pietietiškaji (Italija, Ispanija, Graikija, Portugalija) modelius. 
Pirmojoje Šeimos koncepcijoje pabrèžiama, kad šeimos politikos priemonès turètų būti nukreiptos ne tik i pažeidžiamiausią ir labiausiai stokojančią paramos šeimą, bet turètų skatinti ir palankios aplinkos kūrimą. Todèl koncepcijoje tarp pagrindinių principų nurodyta skatinti šeimų ir individų autonomiškumą bei aktyvumą siekiant spręsti problemas (Ten pat). Nors minètoje koncepcijoje subsidiarumo principas konkrečiai neivardytas, tačiau pripažistama, kad šeima yra tas socialinis vienetas, kuris geba stiprinti save ir kitus, jeigu tam sudaromos palankios sąlygos. Patvirtinus šią šeimos politikos koncepciją (Ten pat), šeimos politikos sąvoka vartojama kaip atskira šalia socialinès apsaugos ar socialinès politikos (Jančaitytė, 2006).

Tačiau mokslininkų atliktos analizès atskleidè, kad 1996 metais pasikeitus Vyriausybei, koncepcijos nuostatai nebuvo igyvendinti ir šeimos politika prarado trumpam igytą kryptingumą. Šeimos politika toliau formavosi pagal neaiškų politini scenarijų, daugiausiai imantis piniginiu priemonių: didinat motinystės / tėvystės išmokas, ivvedant pašalpas vaikams.

Tad galima pastebėti, kad šeimos politika kurta ,iš viršaus“: šeimoms ,nuleidžiant" tik finansinę paramą, neskatinant jų savarankiškai gerinti savo gerovès, pilietinès visuomenès dalyvavimo šiame procese. Šiek tiek aiškesnè valstybès pozicija dèl šeimos politikos tapo 2004 metais, patvirtinus Gyventojų (demografinès) politikos strategiją, kur ịvardijama, kad esminès šeimos situacijos silpnosios pusès yra šeimos nestabilumas, didelis skyrybų skaičius, nepakankamai išplètotos paslaugos šeimoms, tarpinstitucinio bendradarbiavimo trūkumas, ribotos būsto pasirinkimo galimybès, menkas tẻvų dalyvavimas vaiko švietime ir kt. Strategija apibréžia valstybės misijac, kuri išreiškiama per palankios socialinės ir ekonominès aplinkos šeimoms kūrimą (racionali paramos šeimai politika, vaiko gerovès, užimtumo, apsirūpinimo būstu politika, sveikatos, vaikų priežiūros, švietimo, socialiniu paslaugų tinklo kūrimas) bei bendradarbiavimą su savivaldybemis, nevyriausybinėmis organizacijomis ir bendruomene, sprendžiant šeimos gerovès kèlimo klausimą. Tačiau galima pritarti nuomonei, kad ,siekiant realizuoti sukurtas konceptualias prielaidas būtina aktyvi politikos kūrèjų pozicija ir aiškus integruotas ir kryptingas veiksmų planas, o ne tik deklaruojamos raštu kryptys ir tikslai“ (Stankūnienè ir kt., 2005, p. 158).

Parengtoje ir priimtoje strategijoje galima įžvelgti subsidiarumo principo akcentų: norima stiprinti šeimą, kad ši būtų pajègi atsakingai atlikti savo funkcijas, be to, iš dalies atsakomybe už šeimos gerovę perduodama trečiajam sektoriui (nevyriausybinèms organizacijoms), finansuojant ju parengtus projektus ir paslaugu plètrą (pvz., krizės centrų ar šeimai stiprinti skirtų paslaugų). Tačiau, kaip sakyta, pastebimas menkas savivaldybių vaidmuo igyvendinant šią strategiją, o patirtis parodè, kad daugelis užsibrèžtu punktų liko tik deklaracijomis. 
Paminėtinas dar vienas svarbus šeimos politikos kūrimo žingsnis - 2008 m. priimtas programinis dokumentas - Valstybinè šeimos politikos koncepcija, kurioje nurodomos šeimos politikos kryptys, principai ir tikslai, patvirtinama LR Konstitucijoje įtvirtinta nuostata, kad šeima yra valstybès ir visuomenès pagrindas. Koncepcijoje pažymimas šeimos, kaip pirminės ir svarbiausios bendruomenès / institucijos, išskirtinumas, apibūdintos pagrindinès šeimos raidos ir jos gyvenimo sąlygu problemos Lietuvoje, apibrèžiamos šeimos funkcijos ir pirmą kartą teisès akte pateikiama šeimos sąvoka: „Šeima - sutuoktiniai ir jų vaikai (ivaikiai), jeigu ju yra. Šeima taip pat gali būti nepilna ar išplèstinè“ (Valstybinè šeimos politikos koncepcija, 2008). Tiesa, koncepcija yra programinis dokumentas, nurodantis šeimos politikos kryptis ir išreiškiantis tam tikrą valstybės poziciją šeimos atžvilgiu, bet ne istatymas, kuriantis teises ir pareigas bei ipareigojantis jų laikytis (Vaičaitis, 2009).

Koncepcija sulaukė daug diskusijų ir prieštaringų nuomonių, ypač dèl šeimos sąvokos, dèl jos sąsajų su santuoka, deja, dèl šios dalies neretai sumenkinamas visas šio dokumento turinys ir jo vertè. $2011 \mathrm{~m}$. rugsèjo 28 d. LR Konstitucinis Teismas priėmė sprendimą, kad toks apibrèžimas prieštarauja Lietuvos Respublikos Konstitucijai.

Koncepcijoje kalbama apie nepalankią šeimai aplinką: būsto, darbo ir pareigu šeimoje suderinamumo problemos, nepakankamai išplètotos socialinès pagalbos ir paramos šeimai priemonès, kt. Koncepcijoje ịvardijami ir valstybinès šeimos politikos igyvendinimo principai, tarp kurių paminėtas subsidiarumo principas. Nurodoma, kad ,teikiama pagalba ir parama šeimai palaiko ir skatina šeimos savaveiksmiškumą visose jos gyvenimo srityse, t. y. padeda šeimai pačiai atsakingai vykdyti tai, ką ji gali daryti savo jègomis, o ne perima ir dubliuoja jos funkcijas“. Todèl šeimos subsidiarumui palaikyti ir stiprinti turi būti rengiami šeimotyros ir šeimos konsultavimo specialistai, plètojama švietimo ir socialinès pagalbos sistema, kuriant jaunimo rengimo šeimai, tėvǔ švietimo ir konsultavimo programas, šeimų tarpusavio pagalbos grupes, padedančias šeimoms spręsti iškylančias problemas ir stiprinti šeimos stabilumą (Valstybinè šeimos politikos koncepcija, 2008).

Koncepcijoje akcentuojama ir tai, kad plètojant socialinę paramą ir paslaugas šeimai siekiama glaudžios socialinès partnerystės, paremtos bendruomeniškumu, savitarpio pagalba, žinybų bendradarbiavimu, panaudojant nevyriausybinių organizacijų potencialą, profesini pasirengimą ir patirti socialinių paslaugų teikimo srityje. Vis dėlto daugelis Lietuvoje socialines paslaugas teikiančių istaigų turi biudžetinès įstaigos statusą, o jų steigèjas yra valstybė arba savivaldybė. Tačiau darytina išvada, kad esamų priemonių nepakanka kurti palankesnes sąlygas ir aplinką šeimoms. 
Taigi nepaisant prieštaringų vertinimų, koncepcija visgi žymi svarbų valstybės žingsnį ir posūkị kuriant mūsų šalies šeimos politiką. Štai 2008-2012 m. Vyriausybès programoje dèl šeimos politikos, be ịvairių pagalbos priemonių šeimai igyvendinimo, ivardyti siekiai ir isipareigojimai igyvendinti koncepcijos nuostatas, akcentuojant šeimos svarbą visuomenès ir valstybès gyvenime. Priemonių plane pastebimas akcentas traktuoti šeimą kaip integralų darinį ir atsižvelgti ị vertybinę jos dimensiją (Dẻl LR Vyriausybès 2008-2012 m. programos igyvendinimo priemonių patvirtinimo, 2009).

Reikšminga ir tai, kad Valstybinès šeimos politikos koncepcijos pagrindu parengtas ir $2010 \mathrm{~m}$. spalio $1 \mathrm{~d}$. pasirašytas Nacionalinis susitarimas dèl šeimai palankios aplinkos kūrimo (toliau - Nacionalinis susitarimas). Dokumentą inicijavo ir parenge NVO, Socialinės apsaugos ir darbo ministerija, LR Seimo Socialiniu reikalų ir darbo komitetas, jam pritare daugelis frakcijų ir partijų (LR Seimo pranešimas, 2010). Rengiant Nacionalini susitarimą pasiūlymų teikè ir diskusijose dalyvavo daugiau nei penkiasdešimt visuomeninių organizacijų, pavieniai asmenys, dokumentas pateiktas visuomenei svarstyti. Paslaugų ir infrastruktūros šeimai plètra, teigiamo visuomenès požiūrio į šeimą stiprinimas, šeimos gerovès ir materialaus saugumo užtikrinimas bei sąlygų igyvendinti šeimos prokreacinę funkciją gerinimas - tai pagrindiniai Nacionaliniame susitarime numatyti tikslai, kurių siekiama kuriant šeimai palankią aplinką. Kaip žinia, Nacionalinis susitarimas taip pat nèra isstatymas, kurị privalu vykdyti ir ị kurị privaloma atsižvelgti rengiant istatymus ir kitus teisès aktus. Tačiau svarbus šio susitarimo igyvendinimo žingsnis buvo 2010 m. prie LR Seimo sudaryta Visuomeninè Nacionalinio susitarimo igyvendinimo priežiūros taryba, kurioje dalyvauja šeimų interesams atstovaujančios NVO (Lietuvos Respublikos Seimas, 2010). Tarybos užduotis - stebėti, kaip igyvendinami Nacionalinio susitarimo priimti palankios aplinkos šeimai kūrimo veiksmai.

Taigi Nacionalinis susitarimas ir jo priežiūros taryba yra bene ryškiausi valdžios institucijų ir NVO, pilietinès visuomenès ir šeimų bendradarbiavimo pavyzdžiai šeimos politikoje: nuomonę dèl Nacionalinio susitarimo išreiškẻ daugiau nei trečdalis šalies savivaldybių ir jam pritare, jo turinį svarstė ir diskutavo parlamentinès politinès partijos, politikai, kartu su suinteresuotujų visuomeninių organizacijų atstovais. Svarbu ir tai, kad šeima šiame dokumente įvardijama kaip savaime turinti ištekliu ir gebanti kurti savo bei visuomenès gerovę, kaip akcentuojama subsidiarumo koncepcijoje, o ne tik reikalaujanti pagalbos ir išlaikymo.

Pravartu paminèti ir kitus dokumentus, kurie susiję su poveikiu šeimos aplinkai ir tiesiogiai šeimai, kaip antai Valstybès pažangos strategija „Lietuva 2030“ (2012), kurioje ivvardyti veiksmai, stiprinantys šeimą: numatoma formuoti teigiamą požiūrị i šeimą, kurti kompleksinių paslaugų šeimai sistemą, ypatingą dèmesį 
skiriant šeimos krizių prevencinei veiklai ir darnių tarpusavio santykių puoselëjimui, skatinti kūrybingą, atsakingą ir atvirą asmens ugdymą šeimose, stiprinti bendruomenes ir kt.

Be to, svarbu pažymėti, kad 2008-2012 m. Vyriausybè, tęsdama pagrindinę nuostatą - stiprinti šeimą, itvirtino Vyriausybès 2012 metų veiklos prioritetą: „Stipri šeima - stipri bendruomenè“. Juo remiantis, numatyta formuoti teigiamą požiūrị i šeima, sudaryti sąlygos derinti šeimos ir darbo įsipareigojimus, skatinti šeimas aktyviau dalyvauti ekonomineje ir visuomeninejje veikloje, didinti paslaugu šeimai ìvairovę, suteikiant daugiau igaliojimų bendruomenių ir šeimų organizacijoms, skatinant jų kūrimą. Vyriausybè numatè veikti šiomis kryptimis: didinant paslaugų šeimai plètrą ir jų prieinamumą; sudarant sąlygas bendruomenių organizacijoms ir nevyriausybinėms organizacijoms dalyvauti teikiant viešąsias paslaugas; sukuriant šeimos politikos igyvendinimo veiksmų koordinavimo visuose valstybės valdymo lygmenyse schema; itraukiant vietos valdžios institucijas į šeimos politikos kūrimą ir igyvendinimą.

Tačiau Nacionalinio susitarimo priežiūros tarybos veiklos ataskaitoje (Nacionalinio susitarimo dèl šeimai palankios aplinkos kūimo igyvendinimo apžvalga 2010 m. spalio 1 d. - 2011 m. gruodžio m. 15 d., 2012), praejjus metams po Nacionalinio susitarimo prièmimo, teigiama, kad Nacionalinio susitarimo tikslai igyvendinti fragmentiškai ir ne visos atsakingos ministerijos ar kitos institucijos siekia juos igyvendinti. Ataskaitoje kritikuojamos valstybinès institucijos dẻl neveiklumo ir įsipareigojimų nevykdymo kuriant šeimos gerovę, taip pat dèl nesupratimo, kad šeimos politika yra horizontalaus pobūdžio ir, koordinuojama vienos institucijos, turètų būti vykdoma ịvairių sričių institucijų ir organizacijų.

Reikia konstatuoti, kad po 2012 m. LR Seimo rinkimų Tarybos veikla prislopo, tačiau 2013 m. birželio m. Tarybos ir kitu NVO iniciatyva, per Seimo socialinių reikalų ir darbo komitetą pasiūlyta steigti didesnị teisinį svorị turinčią Nacionalinę šeimų tarybą, kuri būtų atsakinga už šeimos politikos kūrimą ir šeimos politikos igyvendinimo vertinima, o i jos sudètị būtų itraukti ne tik NVO atstovai, bet ir šeimų klausimus tyrinejjantys mokslo bei studijų institucijų ekspertai. Klausimas iki šiol LR Seime nesvarstytas, tačiau svarbu, kad keliose miestų savivaldybėse (Vilkaviškio, Kauno, Kaišiadoriu, Širvintų, Radviliškio ir kt.) LR Socialinės apsaugos ir darbo ministerijos bei minètos Nacionalinio susitarimo dèl šeimai palankios aplinkos kūrimo priežiūros tarybos iniciatyva ikurtos visuomeniniais pagrindais veikiančios šeimų tarybos, kurių tikslas - rūpintis šeimų gerove vietinėse bendruomenèse. Apskritai vertinant praeitos kadencijos Vyriausybès (2008-2012) darbą keliant šeimos gerovę, galima pasakyti, kad visgi užsibrèžti svarbūs imperatyvai dèl šeimos instituto liko antrame plane. Iš tikrujų ir čia patvirtinama nuostata, kad vargu ar šeimos ir ịvairūs socialiniai klausimai gali būti prioritetiniai ekonomikos 
vystymo, užimtumo ir kt. klausimų atžvilgiu. Nors jie glaudžiai tarpusavyje susiję. Kita vertus, akivaizdu, kad tam tikriems siekiams ir veikloms igyvendinti reikia ilgesnio laiko tarpo, pokyčiams igyvendinti ir apčiuopiamiems rezultatams pasiekti vienos Vyriausybès kadencijos neužtenka.

Galima teigti, kad 2012-1016 m. Vyriausybès pozicija dèl šeimos politikos išlieka palanki, tačiau keičiasi akcentai: jos programoje kaip prioritetinès iškeliamos kompleksinès veiklos, prisidedančias prie demografinès situacijos gerinimo ir gyventojų senėjimo padarinių įveikimo, prioritetą teikiant vaikų priežiūros ir šeimos bei darbo įsipareigojimų derinimui (Dẻl LR Vyriausybès 2012-2016 m. programos igyvendinimo prioritetinių priemonių patvirtinimo, 2013). Tačiau kol kas ryškesnių pokyčių ir veikimo šioje srityje nefiksuojama. Žinoma, svarbu, kad buvusios Vyriausybės pradètos igyvendinti naujovès būtų tęsiamos, tačiau problema ta, kad keičiantis vyriausybėms neišvengiamai kyla pavojus dar labiau fragmentuoti veiklą ir veikti spontaniškai.

Kaip sakyta, koncepcijos ir Nacionalinis susitarimas yra tik šeimos politikos gairès, programiniai dokumentai, kurių neprivaloma igyvendinti ir jais vadovautis kuriant bei derinant teisès aktus. Šiuose teisès aktuose įvardytos priemonès, pasiūlymai ir rekomendacijos rizikuoja likti tik teorinèmis prielaidomis, kol nèra patvirtintų konkrečių teisès aktų, leisiančių isstatymiškai apibrèžti šeimos politiką ir jos priemones.

Taigi galima konstatuoti, kad aptartuose pastarujų metų teisiniuose dokumentuose atkreiptas demesys i svarbiausias šeimos politikos sritis (darbo ir šeimos sričių derinimas, lyčiu lygybè, vaiko gerovė, vaiko priežiūros paslaugos ir pan.). Tačiau akivaizdu, kad realiai tai neigyvendinama arba igyvendinama tik iš dalies, todèl atrodo, kad idejos ir pasiūlymai lieka tik deklaratyviame lygmenyje. Be to, pasakytina, kad pagrindinis pagalbos organizatorius ir vykdytojas yra centrinès valdžios institucijos, kurios atlieka ne tik priežiūros, bet ir vykdytojų funkcijas. Mažai dèmesio kreipiama į savivaldos lygmenį ir jų funkcijas igyvendinant šeimos politika, lieka periferinis NVO ir pačių šeimų vaidmuo. Be to, pasigendama priemonių, kurios galètų paskatinti šeimas burtis ị bendruomenes ar kitus neformalius darinius, neskatinama šeimų savitarpio pagalba, mažai igyvendinama priemonių, kurios skatintų palankesnị požiūrị i šeimą.

Kaip valstybės ir trečiojo sektoriaus bendradarbiavimo pavyzdys paminètini ir LR socialinès apsaugos ir darbo ministerijos remiami NVO projektai šeimos gerovès srityje. Igyvendinant Nacionalinės gyventojų (demografinę) politikos strategiją, nuo 2009 m. finansuojami Nevyriausybinių organizacijų, dirbančiu šeimos gerovés srityje, veiklos projektai, kurių tikslas - skatinti savarankiškos ir gyvybingos šeimos, pagrịstos narių savitarpio pagalba ir atsakomybe, issitvirtinimą (Konkurso nuostatai, 2011, 2012). Projektine veikla per NVO, net ir turint minimaliu 
lèšų, siekiama stiprinti šeimas ir sudaryti sąlygas ir galimybes joms pačioms telktis bei veikti. Galima būtų teigti, kad NVO veiklos ir darbo su šeima finansavimas yra tam tikras subsidiarumo pavyzdys, kadangi valstybė taip stiprina pilietini sektorių. Tačiau reikètų atkreipti dėmesị ir ị tai, kad valstybè, finansuodama projektus, tampa konkrečiu paslaugų užsakovè, kuriai vèliau atsiskaitoma, todèl iš esmès veikla igyvendinama pagal valstybės nurodymus, o ne realius šeimų poreikius, ir NVO veikimo laisvè vis dèlto yra labiau formali. Tad nors iš esmès NVO veikla yra nevaržoma ir skatinama, bendradarbiavimas tokiu atveju remiasi tik lěšų paskirstymu ir atsiskaitymu už jų panaudojimą, o aktyvaus dalyvavimo ir realios partnerystės, kaip tai akcentuoja subsidiarumo principas, pasigendama.

\section{Subsidiarumas Lietuvos šeimos politikoje ekspertų požiūriu}

Siekiant atskleisti, kaip subsidiarumo principas igyvendinamas šeimos politikoje, atlikti interviu su ekspertais, taikant iš dalies struktūruoto interviu metodą. Ekspertai atrinkti tiksline atranka. Kaip svarbiausias atrankos kriterijus pasirinkta kompetencija, kuri nustatyta dviem rodikliais: ne mažesnè kaip 2 metu darbo patirtis šeimos politikos srityje ir vadovaujančios pareigos įstaigoje, nes daroma prielaida, kad vadovaujančias pareigas einantis asmuo turi sprendimo prièmimo galia, todèl nuo jo gali priklausyti tarpinstitucinis bendradarbiavimas. Apklausti 5 asmenys - po 2 asmenis iš skirtingų institucinių lygmenų: 2 asmenys atstovavo Socialinės apsaugos ir darbo ministerijai, 1 asmuo -savivaldybei (pasirinkta Vilniaus $\mathrm{m}$. savivaldybè), 2 asmenys - NVO vadovai (vienas respondentas atstovavo šeimas vienijančiai organizacijai, kitas - paslaugas šeimai teikiančiai NVO).

Duomenys analizuoti remiantis Ground theory atvirojo kodavimo metodologija (Corbin, Strauss, 2008). Straipsnyje pateikiamas apibendrintas ketvirtasis duomenų analizès ir interpretacijos etapas - tarpusavyje lyginami iš visu interviu gauti duomenys, išskiriant juos ił temines kategorijas, papildomai pateikiamos ekspertų rekomendacijos.

\section{1. Šeimos politikos ir socialinès politikos ribos}

Apklausos metu respondentai buvo linkę pažymèti, kad nèra iki galo aišku, kas yra šeimos politika. Kaip minèta ankstesniame paragrafe, šeimos politika dažnai tapatinama su socialine politika. Respondentai interviu metu pažymėjo, kad sudètinga atrasti elementų, kurie apibrèžtu socialinès ir šeimos politikos ribas. Kadangi šeimos klausimai yra labai platūs ir apima ịvairius gyvenimo tarpsnius bei iqvairias sritis, šeimos politiką sudètinga reglamentuoti ir apriboti ịstatymais. 
Be to respondentai pažymejjo, kad esama šeimos politika yra paini dẻl strategijos trūkumo ir klaidingų, t. y. ne į šeimą orientuotų, prioritetų. Apklausos dalyviai taip pat pažymėjo, kad reglamentuoti šeimos politiką šiuo metu sudètinga, nes iš karto pradedama kalbėti apie tam tikrų socialinių grupių diskriminavimą. Be to, respondentai nurodè, kad Konstituciniam Teismui pripažinus Šeimos politikos koncepcijoje nurodytą šeimos apibrèžimą kaip prieštaraujantị LR Konstitucijai, pasunkèjo NVO, dirbančių šeimos gerovès srityje, galimybės dalyvauti kuriant šeimos politiką. İdomu tai, kad respondentai, nepaisant juridinio organizacijos, kuriai atstovauja, status, teigè, kad dažniausiai šeimos politika nukreipta i pažeidžiamas socialines grupes, socialinès rizikos grupès šeimas. Tai lemia, kad nepakankamai dèmesio skiriama darnioms šeimoms, kurios veiksmingai gali prisidèti prie gerovès kūrimo. Respondentai, atstovaujantys nevyriausybinėms organizacijoms, pažymėjo, kad tik po akcijos „Šeima - gyvybės lopšys“, kuri vyko 2007 metu balandžio mėnesî, prasidejjo tam tikras šeimos politikos atgimimas. Respondentai minejjo, kad eisenos tikslas - parodyti, kad Lietuvoje yra žmonių, kuriems šeima yra vertybe, ir tokias šeimas irgi reikia remti. „Mes visi dalyvavome, tokia taiki demonstracija, turinti tikslą parodyti visuomenei, kad šeimos yra gyvos, sveikos, trykštančios gyvenimu ir iš tikrujų nepretenduoja i kažkokias dideles pašalpas, tiesiog nori palaikymo iš valstybès pusės ir sąlygų sudarymo." Kaip minèjo respondentai, NVO, dirbančios šeimos gerovès srityje, veikia šeimų labui, jos siekia stiprinti visas Lietuvos šeimas, ne tik tas, kurios išgyvena krizę. NVO veiklą šeimos politikos srityje apima ir renginių šeimoms organizavimas bei tiesioginis atstovavimas šeimų interesams. Respondentai, atstovaujantys nevyriausybinių organizacijų ir ministerijos lygmeniui, nurode, kad kurdami istatymus, tarp jų ir ¿sstatymus, kurie susiję su šeimos politika, dažniausiai vadovaujasi savo patirtimi ar atstovauja savo interesams. Tą patvirtinančiose citatose nurodyta, kad istatymų leidejjai yra subjektyvūs: ,Jeigu koks nors žmogus turi asmeninių nuoskaudų šeimos srity, tai jis dažnai blokuoja su šeima susijusius klausimus, tiesiog asmeniškai neremia kokių nors įstatymų ar nurodymų.

\subsection{NVO dalyvavimas šeimos politikoje}

Kai NVO organizacijos dalyvauja kuriant šeimos politiką, sudaromos sąlygos kurti politiką „,iš apačios“, o tai lemia didesni piliečiu itraukimą, subsidiarumo apraiškas visuomenèje. Respondentai, atsakinėdami į klausimą apie šiuo metu sudaromas galimybes nevyriausybinėms organizacijoms dalyvauti kuriant šeimos politika, išskyrẻ keletą pagrindinių aspektų, nuo kurių priklauso NVO galimybės dalyvauti politikoje. Vienas esminių dalyku - NVO turi galimybę kurti šeimos politika, dalyvaudamos visuomeninès igyvendinimo priežiūros taryboje, kuri ste- 
bi Nacionalinio susitarimo dèl šeimai palankios aplinkos kūrimo igyvendinimą. Visuomeninè taryba formaliai turi prižiūrèti ir kontroliuoti atitinkamų institucijų, susijusių su šeimai palankios aplinkos kūrimu, veiklą ir rezultatus, tačiau respondentai abejoja dèl tarybos veiklos efektyvumo, kadangi kyla klausimas, kiek ji gali turèti įtakos šeimoms palankių îstatymų prièmimui. Kita vertus, kaip teigè respondentai, minèta taryba yra puiki priemonè užmegzti dialogą su valdžios institucijomis. Apklausos dalyviai nurodè, kad formaliai galimybès dalyvauti politikoje sudaromos bet, kiek pačios NVO gali jomis pasinaudoti, priklauso nuo jų atkaklumo ar valdžios institucijų palankumo ir geros valios. Respondentai nurodè, kad svarbu pačioms NVO nuolat domėtis ir aktyviai reikšti savo poziciją dèl priimamų programų ar teisės aktų. Kalbant apie valdžios institucijų bendradarbiavimą su NVO, idomu tai, kad ekspertai savo atsakymuose nurodydavo, jos bendradarbiavimas remiasi NVO finansavimu, o sumažinus skiriamas lěšas, bendradarbiavimas sumažèja arba jo iš viso nebelieka. Ypač tai pabrèžè savivaldybès atstovas. Respondentu teigimu, tos organizacijos, kurios jau ne vienerius metus igyvendina šeimos gerovès projektus, galètų atstovauti šeimos interesamss. Keli ekspertai minejo būtinybę savivaldybėse ikurti Šeimų tarybas, kurios būtų sudarytos iš „,visuomenininkų“ ir aktyvių šeimų bei turètų patariamojo organo funkciją. Be to, svarbu, kad Šeimos tarybos remtųsi ne savo asmenine, o gyvenamosios vietovès daugumos nuomone.

Ekspertai kelissyk minėjo nepakankamą valdžios ir nevyriausybinių organizacijų bendradarbiavimą, kuris, kaip minèta, priklauso nuo NVO aktyvumo ir valdžios institucijų geros valios. Išskyrus respondentu atsakymus į atskiras kategorijas, nustatyta, kad valdžios institucijos su NVO bendradarbiauja tik formaliai, jų nuomonė išklausoma, bet retai kada i ją atsižvelgiama. Kaip viena iš priemonių, kurią paminėjo respondentai, nurodytas struktūruotas bendradarbiavimo reglamentavimas, galintis užtikrinti nuolatinius sąveikos mechanizmus tarp NVO ir valdžios institucijų. Respondentų nuomone, nors valdžios atstovų spaudimas nenaudingas patiems valdininkams, jis užtikrina tikraji demokratinị dalyvavimą. Tą ypač pabrěžè ministerijos lygmeniui atstovaujantys respondentai.

Kalbant apie NVO veiklos kokybę ir efektyvumą, ekspertų nuomonės išsiskyrè dviem kryptimis. Respondentai, atstovaujantys NVO, teigè, kad jos teikia tinkamesnes socialines paslaugas, kadangi jų veikla lankstesnè, čia žmonès dirba iš entuziazmo ir pašaukimo, yra motyvuoti, išsikelia savanorystės išteklius, todèl šios organizacijos geba užtikrinti kokybiškas paslaugas už mažesni atlygị. Tačiau pagrindinė NVO problema, kurią akcentavo respondentai, yra veiklos tęstinumas ir kvalifikuotu specialistu pritraukimas bei išlaikymas, esant nepakankamam ir epizodiškam NVO finansavimui. Panašiai teige ir ministerijos lygmeniui atstovaujantys respondentai, nors jie taip pat pabrèžè, kad ne visos NVO yra pajègios užtikrinti kokybiškas paslaugas, todèl kiekvieną NVO reikia vertinti atskirai. Sa- 
vivaldybès lygmeniui atstovaujantis respondentas teigè, kad socialinių paslaugu kokybė nuo organizacijos juridinio statuso ar steigejjo nepriklauso, nes yra reglamentuotos higieninès normos, reikalavimai dèl darbuotojų kvalifikacijos, programų, todèl teikiamos paslaugos turi atitikti nustatytus reikalavimus, pagal kuriuos ir galima nustatyti, ar paslaugos yra kokybiškos. Paslaugas, kurios atitinka reglamentą, be jokių išlygų turi teikti ir savivaldybès ịsteigtos įstaigos, ir nevyriausybinès organizacijos.

Galima sakyti, kad pagrindinis NVO trūkumas vis dèlto susijęs su NVO iniciatyvumo ir aktyvumo stoka. Visi ekspertai tą ịvardijo kaip vieną esminių kliūčių, kodèl NVO mažai pripažistami valdžios institucijų ir piliečių. Ekspertai, kalbėdami apie NVO trūkumus, pažymėjo, kad NVO dažniausiai susitelkusios į veiklos vykdyma, o ne ị savo ir piliečių nuomonès ginimą bei atstovavimą, veiklos viešinimą, visuomenès informavimą, valdžios institucijų spaudimą.

Apibendrinant ekspertų nuomones, galima teigti, kad NVO susikuria, kad teiktų konkrečias paslaugas ir būtent joms gautų finansavimą, jų paslaugos paprastai yra kokybiškos, tačiau pačių piliečių jie neatstovauja, tam tikra prasme atsiriboja ir nuo politikos kūrimo. Vienas iš ekspertų, atstovaujantis ministerijos lygmeniui, ¿vardijo, kad daug aktyviau dalyvauja ir pasisako tie, kurie yra prieš šeimos politiką, respondento žodžiais, ,antišeimiški“. Ekspertai vardijo priemones, kurių turètų imtis NVO, siekdamos didintis savo pripažinima, veiklos efektyvumą ar siekdamos gauti didesni finansavimą. Kaip vienas esminių dalyku ịvardytas telkimasis, bendradarbiavimas ir aktyvus viešumo siekis, kuris leidžia NVO priarteti prie valdžios institucijų. Pašnekovų nuomone, rodydamos savo pasiekimus visuomenei, nuolat viešindamos savo veiklą, rezultatus, inicijuodamos dialogą su valdžia, NVO rodo piliečiams savo reikalingumą, o tai ilgainiui skatina piliečiu ittraukimą i NVO veiklą bei politikos kūrimą spaudžiant valdžią: „Labai norètųsi, kad organizacijos irodytų ir visuomenei savo reikalingumą toki, kad ir rinkejjai valdininkus irgi spaustų ir sakytų, o kodèl nepasisako nevyriausybininkai.“ Nors ekspertai kaip vieną iš trūkumų i̇vardijo konkurenciją tarp pačių NVO ir nepakankamą bendradarbiavima, keli ekspertai nurodè priemones, kurios galètų padèti tą konkurenciją mažinti - tai dialogas, bendra veikla ir bendras darbas. Tai ilgainiui galètų paskatinti tinklo atsiradimą. NVO atstovaujantis respondentas sutiko, kad konkurencija tarp NVO yra, tačiau geranoriškai stengiamasi bendradarbiauti, dalytis informacija ir derinti veiklas rengiant projektus.

Tyrime dalyvavę ekspertai nurode, kad šiuo metu NVO skiriamas nepakankamas finansavimas ir pagrindinè problema - finansavimo tęstinumo užtikrinimas. Būtent tęstinis ir nuolatinis finansavimas leistų NVO labiau ịsitraukti i politikos kūrimą vykdant veiklą. Kaip minèta, dauguma ekspertu sutinka, kad NVO yra pajègios teikti kokybiškas ir efektyvias paslaugas, tačiau neturi pakankamai lèšu 
išlaikyti kompetentingus darbuotojus. Ekspertai pažymèjo, kad NVO žino, kaip reikia dirbti, o valdžios atsakomybė - užtikrinti nuolatini finansavimą, kad veikla būtų tęstinè. Kaip vieną iš galimų priemonių ekspertai nurodè paslaugų pirkimą, tai užtikrintų nuolatinį finansavimą, leistų efektyviau planuoti tolesnę veiklą. Vienas iš ekspertu, atstovaujantis NVO lygmeniui, nurodè, kad NVO, turèdamos didesni finansavimą, galètų prisidèti prie šeimos konsultantų rengimo universitetuose, kurių šiuo metu trūksta.

\subsection{Piliečių ir šeimų ịtraukimas ị šeimos politikos kūrimą}

Ekspertu teigimu, svarbu kurti šeimos politiką „,iš apačios“, nes tik pačios šeimos gali žinoti, ko joms labiausiai trūksta, ir tik taip gali būti kuriama veiksminga, i piliečių gerovę nukreipta politika. Kaip teigè vienas iš pašnekovu, Lietuvoje „žmonès dažnai stokoja tradicijos ir patirties dalyvavimo vienose ar kitose visuomeninėse iniciatyvose, stokoja patirties ir igūdžių išreiškiant bendrą interesą ir siekdami jo igyvendinimo“. Todèl, suprantama, sunku ittraukti pavienius žmones ir šeimas kurti politika, skatinti išreikšti savo poziciją ir ginti savo interesus.

Kalbėdami apie piliečių ir šeimų ịtraukimą ị šeimos politikos kūrimą, ekspertai aktyviai vardijo priemones, kurios galètu paskatinti piliečių dalyvavimą politikoje, minejjo naudą, kokią turètų visuomenè. Viena esminių priemonių - burtis ị iniciatyvines grupes, nes taip būtų lengviau atstovauti ir pasiekti rezultatų. Tokị interesų atstovavimą pasiūlè savivaldybès lygmeniui atstovaujantis ekspertas. Kaip minėjo ekspertai, šeimoms dažnai nedrąsu dalyvauti, todèl būtina ašis, apie kurią galètų burtis šeimos. Ja galètų būti bendruomenè ar organizacija, galbūt net savivaldybė. Šeimų dalyvavimas galètų būti reglamentuotas taip pat kaip ir NVO bendradarbiavimas su valdžios institucijomis. Respondentai, atstovaujantys ministerijos lygmeniui, teigé, kad protinga valstybė turètų suteikti „tribūną“ aktyviems piliečiams ir šeimoms, nes tai yra demokratinio principo valdymo raiška. Ekspertai teigè, kad kiekviena šeima yra savo problemų sprendèja, todèl atsakomybès už šeimos gyvenimą negalima permesti institucijoms. Tarp priemonių, kurios galètų padèti ịtraukti šeimas i politikos kūrima, ekspertai ịvardijo tyrimus, apklausas, viešas diskusijas, kur galètų pasisakyti aktyvios šeimos. Ekspertai, nors jų tiesiogiai nesiteirauta apie subsidiarumo principa, i̇vardijo svarbiausius subsidiarumo principo elementus, kurie turi būti pasiekti visuomenèje. Ekspertai teigè, kad „iš viršaus“ primesta pagalba neveiksminga, pagalbos turètų ieškoti pačios šeimos. Iš esmès šeimos gali padèti vienos kitoms mažiausiomis sąnaudomis, todèl visuomenèje turètų būti skatinama savitarpio pagalba. Respondentai minèjo, kad protinga valstybe turi leisti šeimoms pasisakyti, ir neturètų kištis į privatų šeimos gyvenimą, kol ši sugeba savarankiškai funkcionuoti. 
Visi ekspertai atstovavimą šeimų interesams įvertino kaip nepakankamą ir neveiksmingą sritị. Vieni teigè, kad trūksta organizacijų, tikrai galinčių tą daryti. Kiti ekspertai nurodè, kad neįmanoma atstovauti šeimoms, kurios niekur nedalyvauja, o bendrai visiems žmonėms atstovaujama per rinkimus, todėl žmonės turi atsakingai juose dalyvauti. Be to, pažymèta, kad vietinès bendruomenès galètų atstovauti savo bendruomenès narių interesams, tačiau trūksta aktyvių vietinių iniciatyvų.

Respondentų teigimu, NVO per mažai viešina savo veiklą, nėra iniciatyvios reikšdamos savo poziciją ir skirdamos savo laiką būtent tokioms veikloms, kaip raštų, straipsnių rengimas. Respondentai nurodè, kad ir patys piliečiai, norintys dalyvauti politikoje ir siekiantys, kad jų nuomonès būtu išgirstos, o interesai atstovaujami, vertetų burtis į iniciatyvines grupes, steigti visuomenines komisijas prie savivaldybių - toks būdas gerokai veiksmingesnis. Tokių ir panašių iniciatyvinių grupių steigimas galètu prisidèti prie šeimų dalyvavimo kuriant šeimos politiką, savitarpio pagalbos plètros, nes šeimos turètu progą puoselèti ryši vietinėse bendruomenèse, o tai galètu tapti puikia prielaida subsidiarumo principo implikacijai šeimos politikoje.

Nors ir netiesiogiai, respondentai minejjo subsidiarumo principo elementu reikšmingumą šeimos politikoje. Jų teigimu, svarbu suteikti galios pačioms šeimoms prisidèti prie politikos kūrimo tiesiogiai dalyvaujant sprendimų prièmimo procese ir per didesnių galių NVO suteikimą.

Interviu metu pateiktas ekspertų rekomendacijas NVO, kaip jos galètų padidinti savo veiklos efektyvumą ir politini dalyvavimą, būtų galima taip apibendrinti: puoselèti dialogą tarp ịvairių institucijų ir subjektų, siūlyti valdžios institucijoms atsižvelgti į šeimų poreikius, kurti tėvų ir šeimų bendruomenes (pvz., mokyklose), plèsti teikiamų paslaugų, kurios skirtos šeimos santykių gerinimu, spektrą. Tačiau, kaip sakyta, pasiūlymams igyvendinti būtinas aktyvus issitraukimas ir kolektyvinis veikimas.

\section{Išvados}

Literatūros ir dokumentų analizè, empirinio tyrimo duomenys leidžia daryti išvada, kad subsidiarumo principas Lietuvos šeimos politikoje pasireiškia labai minimaliai ir labiau deklaruojamas nei praktiškai igyvendinamas. Be to, išryškèjo, kad subsidiarumo koncepcija Lietuvoje traktuojama redukuotai: veikiau kaip valstybinių funkcijų delegavimas žemesnio lygmens institucijoms ir retai - kaip savarankiškų funkcijų savivaldos institucijoms, pilietinėms iniciatyvoms suteikimas, kaip socialinès tvarkos modelis valstybejje, kai centrinès ir vietinès valdžios institucijos, savanoriškai susivienijusios organizacijos ir piliečiai glaudžiai bei ak- 
tyviai bendradarbiauja, dalijasi atsakomybe teikiant ivvairias socialines paslaugas ir pagalbą šeimoms. Nesvarstomos ir neigyvendinamos priemonès sudaryti sąlygas šeimoms telktis ir veikti, skatinti pilietinio sektoriaus dalyvavimą kuriant šeimos politiką ,iš apačios“.

Analizè rodo, kad teisès aktuose ir su šeimos politika susijusiuose dokumentuose atkreiptas dėmesys į svarbiausias šeimos politikos sritis (darbo ir šeimos sričių derinima, lyčių lygybę, vaiko gerovę, vaiko priežiūros paslaugas ir pan.), tačiau iki šiol taikomos priemonès daugiausia nukreiptos į disfunkcines šeimas ir pagalbą joms. Parama, teikiama pajamų testavimo principu, skiriama individualizuotai, tai yra pagal poreiki pavieniams šeimos nariams, neatsižvelgiant i jų priklausymą šeimos dariniui. Akivaizdžiai trūksta priemonių, kurios stiprintų šeimą kaip vienetą, skatintų savitarpio pagalbą visuomeneje, kurtų palankią aplinką šeimų ir pilietinio sektoriaus (pvz., NVO) dalyvavimui šeimos politikoje.

Empirinis tyrimas patvirtino teorinę prielaida, kad šeimos politikos Lietuvoje kūrimą ir igyvendinimą apsunkina jos neaiškumas ir neapibrèžtumas socialinès politikos atžvilgiu. Atlikus tyrimą galima konstatuoti, kad NVO Lietuvoje formaliai sudaromos sąlygos dalyvauti šeimos politikoje, išreikšti savo poziciją ịvairiais klausimais, dalyvauti darbo grupèse ir pan. Tačiau iš esmès NVO dalyvavimas dažnai būna fragmentiškas ir neveiksmingas dèl valdžios instituciju požiūrio i NVO, nepastovaus ir nepakankamo finansavimo bei dèl pačiu NVO iniciatyvumo ir aktyvumo trūkumo. Kita problema - NVO save labiau traktuoja ir veikia kaip paslaugu teikèjai, o ne šeimos politikos kūrèjai, dirbantys aplinkos šeimai gerinimo ir kūrimo linkme, nekalbant jau apie šeimos interesų atstovavimą. Šiuo metu viena realiausių galimybių NVO prisidèti kuriant šeimos politiką - dalyvauti Visuomeninès Nacionalinio susitarimo dèl šeimai palankios aplinkos kūrimo igyvendinimo priežiūros tarybos, kuri stebi Nacionalinio susitarimo igyvendinima, ir savivaldybèse įsikūrusių Šeimų tarybų veikloje.

NVO ir valstybinio bei savivaldos institucijų bendradarbiavimas dažniausiai apibrèžtas valdžios institucijų teikiama finansine parama. Tyrime išryškèjo, kad pagrindinis aspektas, $\mathfrak{i}$ kurị turètų atkreipti dėmesį nevyriausybinès organizacijos, siekdamos didinti savo dalyvavimą politikoje, - viešinti savo veiklą, nes valdžios pripažinimas priklauso nuo to, ar patiems gyventojams, bendruomenėms reikia NVO ir jų paslaugų.

Tyrimas parodé, kad pagrindinis NVO privalumas yra $\mathfrak{i}$ žmogų orientuotas požiūris ir lankstumas teikiant paslaugas. O nepakankamas NVO finansavimas trukdo plètoti tęstinę veiklą ir neleidžia išlaikyti kompetentingų darbuotojų. NVO labiau ịsitraukti i politikos kūrimą leistu įstatymais ir normomis reglamentuotas bendradarbiavimas, tačiau taip kyla grèsmė, kad politika bus kuriama „iš viršaus“, 
kai „nuleidžiama“ prievolè bendradarbiauti, o ne kuriama partnerystè santykio pagrindu - tokiu atveju bendradarbiavimas gali būti taip pat neveiksmingas.

Remiantis tyrimu daroma prielaida, kad visoms struktūroms visuose lygmenyse trūksta dialogo, kuris visoms dalyvaujančioms šalims leistų derinti lūkesčius ir poreikius bei interesus. Tai pasakytina ne tik apie valdžios institucijų ir NVO bendradarbiavimą, bet ir apie NVO bendradarbiavimą su piliečiais.

Gauta 20131015

Pasirašyta spaudai 20140214

\section{Literatūra}

Brugnoli, A., Vittadini, G. (a cura di) (2008). La sussidiarieta' in Lombardia. I soggetti, le esperienze, le policy. Milano: Guerini e associati.

Compendio della Dottrina Sociale della Chiesa. (2005). Vaticano: Libreria Editrice Vaticana.

Corbin, J., Strauss, A. (2008). Basics of qualitative research. Los Angeles: Sage Publications.

Donati, P. (2011). Verso una societa'sussidiaria. Teorie e pratiche della sussidiarieta' in Europa. Bologna: University Press.

Donati, P. (2007). Famiglia e bisogni sociali: la frontiera delle buone prassi. Milano: Franco Angeli.

Gvaldaitè, L. (2012). Subsidiarumas šeimos politikoje: Lombardijos (Italija) modelis. Tiltai, nr. 1: $175-194$.

Guogis, A. (2002). Dèl Lietuvos socialinės politikos modelio. Politologija, nr. 4 (28): 76-95.

Jančaitytè, R. (2011). Šeimos politikos formavimas Lietuvoje. Daktaro disertacija. MRU.

Jančaitytė, R. (2006). Palankios šeimai politikos igyvendinimas Lietuvoje: problemos ir galimybès. Socialinis darbas. Mokslo darbai, nr. 5 (1): 30-37. Vilnius: Mykolo Riomerio universiteto leidybos centras.

Kondratienè, V. (2011). Subsidiarumo principas ir jo taikymas valstybés valdymui ir vietos savivaldai. Daktaro disertacija. MRU.

Laumenskaitè, I. E. (2011). Iššūkiai konstitucinèms vertybèms šiandien. Konferencijos pranešimų medžiaga, Lietuvos Respublikos Seimas.

Markauskaite, Ž. (2005). Subsidiarumo ir solidarumo reikšmė nevyriausybinių organizacijų organizuojamoms bei teikiamoms socialinėms paslaugoms Lietuvoje. Profesinès studijos: teorija ir praktika, nr. 1: 19-25.

Maslauskaitè, A. (2005). Šeima ir šeimos politika. Patirtis ir neokonservatyvios politikos gairès. Demokratinès politikos institutas.

Petružytė, D., Girdzijauskienè, L., Gvaldaitė, L. (2004). Subsidiarumo principas socialiniam darbuotojui sąveikaujant su klientu. Socialinis darbas. Mokslo darbai, nr. 3: 23-34. Vilnius: Mykolo Riomerio universiteto leidybos centras.

Pio XI. (1999). Enchiridion delle encichlic, vol. 5. Bologna: Edizioni Dehoniane.

Stankūnienè, V., Jasilionienė, A. Jančaitytè, R. (2005). Šeima, vaikai, šeimos politika: modernejiimo prieštaros. Vilnius: STI.

Stankūnienė, V., Eidukienė, V. ir kiti (2001). Paramos šeimai politika: samprata ir patyrimas. Vilnius: Lietuvos filosofijos ir sociologijos institutas.

Szczepaniak, J. (2010). Sybsydiarność w polityce społecznej wobec rodziny w warunkach współczesnych między ideą a rzeczywistością. Współczesne wyzwania polityki społecznej wobec rodziny, t. 146. Prace Naukowe Wydawnictwo Uniwersytetu Ekonomicznego we Wrocławiu.

Vaičaitis, V. A. (2009). Valstybinès šeimos politikos koncepcijos teisiniai aspektai. Kodèl šeima? Vilnius: Ciklonas. 
Lijana Gvaldaite, Agnija Kirilova

\section{Teisès aktai ir dokumentai}

Dèl LR Vyriausybės 2012-2016 m. programos igyvendinimo prioritetinių priemonių patvirtinimo. (2013). Lietuvos Respublikos Vyriausybès nutarimas Nr. 228.

Dèl LR Vyriausybės 2008-2012 m. programos igyvendinimo priemonių patvirtinimo. (2009). Lietuvos Respublikos Vyriausybès nutarimas Nr. 189.

Dẻl Valstybės pažangos strategijos „Lietuvos pažangos strategija „Lietuva 2030“ patvirtinimo. (2012). Lietuvos Respublikos Seimo nutarimas. Valstybès žinios, Nr. 61-3050.

Dèl Valstybinès šeimos politikos koncepcijos. (2008). Lietuvos Respublikos Seimo nutarimas. Valstybès žinios, Nr. X-1569.

Dèl šeimos politikos koncepcijos ir veiksmų krypčių. (1996). Lietuvos Respublikos Vyriausybės nutarimas Nr. 362.

Lietuvos nevyriausybiniu organizaciju bendradarbiavimas su valstybès ir savivaldybiu institucijomis bei istaigomis. (2006). Tyrimas. Nevyriausybinių organizacijų ir paramos centras. Prieiga internete: http://www.nisc.lt/ 1t/files.php?start5=0\&kind_id=1

Lietuvos Respublikos Darbo kodeksas. (2002). Valstybès žinios, Nr. 64-2569; Aktuali redakcija (2011). Valstybès žinios, Nr. 146-6848.

Nacionalinès demografinès (gyventoju) politikos strategija. (2004). Valstybès žinios, Nr. 159-5795.

Lietuvos Respublikos piniginès socialinès paramos nepasiturinčioms šeimoms ir vieniems gyvenantiems asmenims įstatymas. (2011). Valstybès žinios, Nr. 155-7353.

Nacionalinis susitarimas dèl šeimai palankios aplinkos kūrimo. (2010). Prieiga internete: http://www3.lrs.lt/pls/ inter2/dokpaieska.showdoc_1?p_id=376067

Nacionalinio susitarimo dèl šeimai palankios aplinkos kūrimo igyvendinimo apžvalga $2010 \mathrm{~m}$. spalio $1 \mathrm{~d}$. 2011 m. gruodžio 15 d. (2012). Prieiga internete: http://www3.lrs.lt/pls/inter/w5_show?p_r=5931\&p_ $\mathrm{d}=126672 \& \mathrm{p} \_\mathrm{k}=1$

Sudaryta Nacionalinio susitarimo dèl šeimai palankios aplinkos kūrimo visuomeninè igyvendinimo priežiüros taryba. (2010). Prieiga internete: http://www3.lrs.lt/pls/inter/w5_show?p_r $=4463 \& p \_d=105868 \& p \_k=1$

The Maastricht Treaty. (1992). Prieiga internete: http://www.eurotreaties.com/maastrichtec.pdf

The Treaty of Amsterdam. (1997). Prieiga internete: http://www.eurotreaties.com/amsterdamtreaty.pdf

\section{MANIFESTATIONS AND PERSPECTIVES OF SUBSIDIARITY IN FAMILY POLICY IN LITHUANIA}

\section{Lijana Gvaldaitė, Agnija Kirilova}

\section{Summary}

According to some researches and social policy experts, subsidiarity topic is becoming more acute with decreasing possibilities of the state, along with the welfare state, to take care of all social risks of their residents (Szczepaniak, 2010; Donati, 2007, 2011; Brugnoli Vittadini, 2008, ect.). This issue covers a wide range of the factors - financial resources, redistribution, organization of service and support, etc., as well as participation of civil society and smaller social groups like non-governmental organizations, local communities, municipalities, families and 
individuals in shaping trends of social and family policy and its implementation. The principle of subsidiarity states that not only public institutions can be actively involved in such a policy, but also various independent "from the bottom" initiatives - their participation provides a more comprehensive and accurate knowledge of the needs of the citizens and contributes to encourage the formation of the more effective policy - thereby creating a multidimensional model of welfare. Subsidiarity can pave the way to various civic participation and representation forms, promote person-oriented support strategies and empowerment. The application of this principle allows achieving a more effective assistance to individuals, reducing the control of public authorities and costs. But at the same time it is clear that the administration of this system is based on specific logic and is quite complex, and putting all the benefits aside, raises a number of dilemmas and risks.

In our country family policy is not subsidiary, but one can notice some manifestations of it - within families and involvement of their associated derivatives, NGOs, providing services to families and other organizations operating in family welfare, municipal and community initiatives. Family policy analysis in this regard is important both scientifically and practically, because there is a noticeable lack of such research and broader discussions involving scientists and professionals related to this field as well as families themselves.

While subsidiarity is little studied not only in Lithuania, but also in the international context, in recent years this concept attracts attention of more and more representatives from economics, management, social policy and social work and other fields: publications by V. Kondratienè (2011), E. Laumenskaitė (2011), L. Gvaldaitė (2006, 2012), Ž. Markauskaitė (2005) D. Petružytè, S. Girdzijauskienè (2004) and other authors. However, in general, there is a lack of information and comprehensive research on this topic.

This article aims at revealing theoretical foundations of the subsidiarity principle, its manifestations and prospects in the current family policy. The following methods were used to disclose the chosen topic: a comparative analysis of scientific literature, analysis of legislation and documents, semi-structured interviews with experts.

Literature and document analysis, data of empirical research let to the conclusion that the principle of subsidiarity in Lithuanian family policy is little manifested and is more declared rather than implemented in practice. Furthermore, it became clear that the concept of subsidiarity in Lithuania is treated as induced: it is seen rather as delegation of state functions to lower level institutions, and rarely as granting independent functions to municipal bodies, civic initiatives, as a model of social order in the state where central and local authorities, voluntary united 
organizations and citizens in close and active cooperation are sharing responsibilities and providing a range of social services and support for families. Moreover, measures, enabling the families to come together and function, promoting the involvement of the civic sector in forming family policy "from the bottom", are not considered and not implemented.

Analysis of the main legal acts and family policy documents revealed that they address key family policy spheres (coordination of work and family, gender equality, child welfare, child care, etc.) but so far the measures are mainly directed to dysfunctional families. Support, provided on income test basis, is individualized, that is, according to the needs of the individual family members, regardless of their membership in the family derivatives. There is a lack measures to strengthen the family as a unit, to encourage mutual aid society, create a supportive environment for families and civic sector (e.g. NGOs) to participate in family policy.

Empirical research has confirmed the theoretical assumption that difficulty for formulation and implementation of family policy in Lithuania was arising from vagueness and uncertainty in social policy. The research allows to come to conclusion that formally in Lithuania NGOs are allowed to participate in family policy, express their positions on various issues, participate in working groups, etc. Essentially, however, the participation of NGOs is often fragmented and ineffective because of the government's approach to NGOs, instability and insufficient funding, as well as lack of initiative and activity from NGOs. The problem also lies in the fact that NGOs treat themselves and act more as a service provider, rather than family policy makers working in the direction of the development and improvement of family friendly environment, and even less - as organizations representing family interests. Currently, one of the most realistic possibilities for NGOs to contribute to the creation of family policy is through Public Supervisory Board for National Agreement regarding implementation of family friendly environment, which monitors the implementation of the National Agreement through family councils located in the municipalities.

NGOs work together with the state and local authorities is mostly defined by financial support provided by the authorities. The research revealed that the main aspect, to which non-governmental organizations should pay attention in order to increase their participation in politics - that is to publicize as governmental recognition depends on whether residents, communities need NGOs and their services.

The study showed that the main advantage of NGOs is a human-centered approach and the flexibility of the service, but the lack of funding prevents NGOs from having continual practice and keeping competent staff. Cooperation regulated by laws and regulations could allow NGOs to become more involved in the 
policymaking, but there is a risk for a policy formation "from the top", where is a lowered obligation to cooperate and not a partnership based relationship - in this case cooperation can also be ineffective.

According to the study it is assumed, that there is the lack of dialog among all the structures at all the levels allowing reconciling expectations, needs and interests. This is true not only of the public authorities and NGOs, but also of the NGOs and citizens. 
